\title{
PEMETAAN EKOSISTEM LAMUN DENGAN DAN TANPA KOREKSI KOLOM AIR DI PERAIRAN PULAU PAJENEKANG, SULAWESI SELATAN
}

\section{SEAGRASS ECOSYSTEM MAPPING WITH AND WITHOUT WATER COLUMN CORRECTION IN PAJENEKANG ISLAND WATERS, SOUTH SULAWESI}

\author{
Turissa Pragunanti Ilyas ${ }^{1 *}$, Bisman Nababan², Hawis Madduppa ${ }^{2}$, \& \\ Dony Kushardono ${ }^{3}$ \\ ${ }^{1}$ Program Studi Teknologi Kelautan, FPIK, Sekolah Pascasarjana IPB, Bogor, \\ 16680, Indonesia \\ ${ }^{2}$ Departemen Ilmu dan Teknologi Kelautan, FPIK-IPB, Bogor, 16680, Indonesia \\ ${ }^{3}$ Pusat Pemanfaatan Penginderaan Jauh, LAPAN, Jakarta, 13710, Indonesia \\ *E-mail: turissa_pragunanti@apps.ipb.ac.id
}

\begin{abstract}
Previous studies showed that water column correction in habitat benthic mapping using remote sensing data can increase the accuracy of the information produced. This study aims to look at the distribution of seagrasses with and without water column correction using object-based classification (OBIA) on the Pajanekang Island. Field data on the distribution of seagrass and non-seagrass of a total of 347 points were taken in July-August 2018 with a transect $1 \times 1 \mathrm{~m}^{2}$. The satellite data used was SPOT-7 imagery acquired on March 27, 2017, with a spatial resolution of $6 \times 6 \mathrm{~m}^{2}$. Within the OBIA classification method, we used several algorithms such as Support Vector Machine (SVM), Bayes, KNearest Neighbor (KNN), and Decision Tree (DT) to map benthic and seagrass habitats. The results showed that the treatment of with and without water column correction in mapping benthic and seagrass ecosystem habitats using several classification algorithms produced no significant difference in the accuracy of classification image product. However, from the four algorithms used, the Bayes algorithm without water column correction produced the highest accuracy value for benthic habitat mapping of $70.36 \%$ and seagrass habitat of $66.47 \%$. The results showed that water column correction did not provide better results in the classification of benthic and seagrass habitats of digital satellite imagery than that of without water column correction.
\end{abstract}

Keywords: algorithm, OBIA classification, Pajenekang Island, seagrass, water column

\begin{abstract}
ABSTRAK
Koreksi kolom air dalam pemetaan habitat bentik menggunakan data satelit dapat meningkatkan nilai akurasi informasi yang dihasilkan, seperti yang telah dilakukan oleh peneliti sebelumnya. Penelitian ini bertujuan untuk melihat distribusi lamun dengan perlakuan dengan dan tanpa koreksi kolom air menggunakan klasifikasi berbasis objek (OBIA) di Pulau Pajanekang. Data sebaran padang lamun dan non lamun sebanyak 347 titik diambil pada Juli-Agustus 2018 dengan transek 1x1 m². Data satelit yang digunakan adalah citra satelit SPOT-7 akuisisi pada 27 Maret 2017 dengan resolusi 6x6 m². Pada penelitian ini metode klasifikasi OBIA menggunakan beberapa algoritma klasifikasi seperti Support Vector Machine (SVM), Bayes, K-Nearest Neighbour (KNN), dan Decision Tree (DT) untuk memetakan habitat bentik dan lamun. Hasil penelitian menunjukkan bahwa penerapan perlakuan dengan koreksi kolom air dan tanpa koreksi kolom air pada pemetaan ekosistem habitat bentik dan lamun dengan menggunakan beberapa algoritma klasifikasi menunjukkan hasil akurasi yang tidak berbeda nyata. Namun demikian, dari empat algoritma yang digunakan, algoritma Bayes tanpa koreksi kolom air memberikan nilai akurasi tertinggi untuk pemetaan habitat bentik sebesar $70,36 \%$ dan habitat lamun sebesar $66,47 \%$. Hal tersebut menunjukkan bahwa koreksi kolom air tidak selamanya memberikan hasil yang lebih baik dalam klasifikasi habitat bentik dan lamun dari citra satelit digital.
\end{abstract}

Kata kunci: algoritma, klasifikasi OBIA, kolom air, lamun, Pulau Pajenekang 


\section{PENDAHULUAN}

Lamun merupakan tumbuhan tingkat tinggi (Anthophyta) yang hidup dan tumbuh terbenam di lingkungan laut yang memiliki rimpang (rhizome), akar, dan berkembang biak secara generatif yaitu perkembangbiakan secara kawin atau seksual pada tumbuhan berbiji satu (monokotil) dan vegetatif yang merupakan perkembangbiakan secara aseksual (Sjafrie et al., 2018), serta tersebar secara luas di seluruh perairan pesisir tropis dan subtropis, dan beriklim sedang (Hossain et al., 2015). Lamun berperan sebagai produsen primer dalam rantai makanan di perairan, habitat bagi biota-biota laut, perlindungan terhadap daerah pesisir, menjaga sumberdaya alam (Waycott et al., 2004), memproduksi karbon organik melalui penyerapan dan pembusukan (Macreadie et al., 2104), serta dapat mendukung pendapatan ekonomi lokal bagi masyarakat di daerah pesisir (Hossain et al., 2015). Selain itu ekosistem lamun juga memiliki peranan penting dalam ekosistem pesisir karena dapat membentuk padang rumput yang luas untuk mendukung keanekaragaman hayati yang tinggi (Traganos et al., 2018). Akan tetapi, menurut Sjafrie et al. (2018) ekosistem lamun juga merupakan eksositem yang rentan mengalami kerusakan akibat dari manusia ataupun faktor alam dan perubahannya sangat dinamis. Oleh karena itu, untuk manajemen ekosistem padang lamun yang baik, diperlukan informasi spasial dan temporal yang lebih akurat.

Informasi ekosistem padang lamun secara spasial dan temporal dapat diketahui dengan melakukan pemetaan perairan dangkal menggunakan teknologi penginderaan jauh dengan memanfaatkan berbagai sensor optik dari berbagai resolusi spasial mulai dari resolusi rendah, sedang, dan tinggi (Yang \& Yang, 2009; Hedley et al., 2009; Dekker et al., 2005). Pemetaan perairan dangkal dengan teknologi penginderaan jauh diperlukan koreksi data untuk mengurangi kesalahan atau efek yang ditimbulkan dari perekaman citra satelit. Hafitz \& Danoedoro (2015) berpendapat bahwa koreksi data citra dilakukan untuk mengurangi kesalahan pada nilai piksel yang terekam, diantaranya adalah pengaruh atmosfer, posisi matahari, dan pengaruh kondisi perairan saat akuisisi data citra. Kondisi perairan merupakan salah satu kesalahan yang cukup berpengaruh terhadap pantulan spektral objek dasar perairan laut dangkal akibat atenuasi pada kolom perairan. Pengaruh kondisi perairan tersebut dapat dikoreksi dengan koreksi kolom air untuk mengurangi kesalahan informasi yang diekstraksi dari subtrat dasar perairan (Budhiman et al., 2013). Koreksi kolom air juga secara eksponensial berpengaruh terhadap penambahan kedalaman perairan. Intensitas cahaya yang masuk ke dalam kolom air akan mengalami proses absorpsi dan hamburan, yang kemudian disebut proses atenuasi, disebabkan oleh adanya komponen optik air yang menyebabkan menurunnya intensitas cahaya secara eksponensial dengan kedalaman kolom air sehingga terjadi reduksi terhadap nilai radiasi pada kolom perairan (Bukata et al., 2018).

$$
\text { Adanya pengaruh kedalaman }
$$
terhadap deteksi citra satelit merupakan fungsi dari panjang gelombang dan kecerahan perairan, yang secara langsung dapat mempengaruhi efek dari koreksi kolom air terhadap penggunaan data penginderaan jauh (Setiawan et al., 2019). Penerapan koreksi kolom air dengan menggunakan algoritma Lyzenga merupakan salah satu metode yang sangat populer digunakan, selain itu menurut beberapa penelitian penerapan metode ini dapat meningkatkan akurasi dari klasifikasi citra digital yang dilakukan (Zoffoli et al., 2014).

Metode klasifikasi multispektral merupakan salah satu metode yang digunakan dalam pemetaan ekosistem lamun yang masuk dalam kategori ekosistem perairan dangkal. Salah satu teknik dari metode klasifikasi multispektral yang cukup berkembang saat ini dalam memetakan 
ekosistem padang lamun adalah dengan menggunakan analisis berbasis objek atau biasa disebut OBIA (Object Based Image Analysis) yang menunjukkan hasil yang efektif dalam teknik ekstraksi citra dengan memanfaatkan algoritma machine learning dalam proses pengklasifikasiannya (Phinn et al., 2011).

Beberapa penelitian sebelumnya secara spasial telah menerapkan metode berbasis objek dengan menggunakan beberapa algoritma machine learning dan menunjukkan hasil yang cukup baik dalam memetakan habitat bentik dasar perairan laut dangkal (Anggoro et al., 2017; Aziizah et al., 2016). Hasil penelitian Mastu et al., (2018) menyebutkan bahwa pemetaan habitat bentik perairan dangkal dengan menggunakan metode OBIA dan penerapan koreksi kolom air menghasilkan tingkat akurasi sebesar $60,04 \%$ untuk 12 kelas dan 64,1\% untuk 9 kelas habitat bentik dengan algoritma SVM. Selain itu penelitian Hafitz \& Danoedoro (2015) juga menunjukkan pengaruh koreksi kolom air terhadap akurasi pemetaan habitat bentik dengan nilai akurasi sebesar 26,01\%, tanpa koreksi kolom air meningkat menjadi $30,34 \%$ dengan koreksi kolom air. Berdasarkan hal tersebut maka diasumsikan bahwa dengan penerapan koreksi kolom air dapat meningkatkan nilai akurasi pada pemetaan habitat bentik perairan dangkal termasuk ekosistem lamun. Pengaruh koreksi kolom air terhadap hasil klasifikasi ekosistem padang lamun dan penggunaan algoritma klasifikasi OBIA yang tepat masih perlu dikaji untuk mendapatkan hasil pemetaan yang lebih akurat dan optimum. Tujuan penelitian ini adalah menentukan tingkat akurasi pemetaan ekosistem padang lamun dengan penerapan koreksi kolom air dan tanpa koreksi kolom air pada metode klasifikasi OBIA dan penerapan beberapa algoritma klasifikasi SVM, Bayes, KNN, dan DT di perairan pesisir pulau Pajenekang, Sulawesi Selatan.

\section{METODE PENELITIAN}

\subsection{Waktu dan Tempat}

Penelitian ini dilakukan pada bulan Agustus-September 2018 di ekosistem padang lamun yang berada di perairan pesisir Pulau Pajenekang, Provinsi Sulawesi Selatan. Secara geografis lokasi penelitian ini terletak

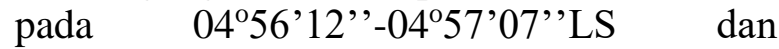
$119^{\circ} 20^{\prime} 02^{\prime}$ ' $-119^{\circ} 21^{\prime} 06^{\prime}$ 'BT. Area titik sampling pada penelitian ini mengelilingi pulau dari arah utara sampai ke selatan (Figure 1).

\subsection{Pengumpulan Data}

Pengumpulan data lapangan menggunakan metode systematic random sampling. Metode tersebut dipilih berdasarkan beberapa pertimbangan di lapangan dan pengetahuan akan kondisi di lokasi penelitian, dipilih secara acak dengan penentuan interval (jarak) tertentu secara berurutan (Congalton \& Green, 2009). Penelitian ini juga menggunakan teknik foto transek yang diambil tegak lurus dari atas. Teknik foto transek ini dilakukan untuk mengidentifikasi objek yang terambil pada setiap transek, menentukan tutupan lamun pada transek kuadran dan dapat juga digunakan sebagai dasar dalam membuat skema klasifikasi habitat bentik dasar perairan pada lokasi penelitian. Pada dasarnya teknik foto transek yang digunakan pada penelitian ini untuk menunjukkan keterwakilan dari ukuran spasial citra yang digunakan pada habitat bentik yang dominan.

Mengingat pemetaan yang kami lakukan adalah pemetaan habitat bentik dan habitat lamun maka kami menggunakan citra satelit resolusi spasial tinggi yang tersedia agar informasi yang dihasilkan lebih detail dan menghasilkan akurasi yang optimum. Berdasarkan hal tersebut citra satelit yang digunakan dalam penelitian ini adalah citra satelit SPOT 7 yang diakuisisi pada tanggal 27 Maret 2017. 
Citra Satelit SPOT 7 memiliki resolusi spasial $6 \times 6 \mathrm{~m}^{2}$ dan terdiri dari empat band citra multispektral (biru, hijau, merah, dan inframerah) ditambah satu band pankromatik. Data citra satelit diperoleh dari Lembaga Penerbangan dan Antariksa Nasional (LAPAN) dalam bentuk level terkoreksi Ortho. Sistem proyeksi yang digunakan adalah sistem koordinat geografik WGS-1984. Data lapangan dikumpulkan dengan menggunakan teknik foto transek $1 \times 1$ $\mathrm{m}^{2}$ (Prabowo, 2018; Anggoro et al., 2017; Roelfsema et al., 2013) pada 196 titik observasi lapangan (Figure 1). Penggunaan transek kuadrat dengan ukuran tersebut dimaksudkan untuk memaksimalkan dalam penentuan atau identifikasi objek dominan yang dilihat secara visual di lapangan ataupun hasil dari foto transek.

\subsection{Analisis Data}

Data lapangan yang dikumpulkan diidentifikasi dan dicatat langsung berdasarkan acuan dari Seagrass Watch (McKenzie et al., 2003). Setelah itu dilakuan pengolahan data citra satelit yang terdiri dari beberapa tahap, pertama preprosesing citra yang terdiri koreksi atmosferik, koreksi geometrik, dan cropping citra untuk lokasi penelitian.

Proses klasifikasi menggunakan metode OBIA dilakukan melalui dua tahapan yaitu segmentasi citra dan klasifikasi pada tiap segmen (Zhang, 2015). Proses segmentasi pada penelitian ini menggunakan algoritma multiresolution segmentation (MRS) dengan besar skala yang digunakan berbeda pada level 1, level 2, dan level 3 . Klasifikasi citra yang terdiri dari 3 level tersebut berdasarkan komposisi lamun adalah level 1 (reef level) yang terbagi atas darat, perairan dangkal, dan laut dalam; level 2 (benthic zones) terdiri dari empat kelas habitat yaitu bentik karang, lamun, pasir, dan rubble; dan level 3 (seagrass cover) merupakan persen tutupan padang lamun yang juga terbagi menjadi tiga kelas tutupan yaitu kaya/sehat, kurang kaya dan miskin. Struktur hierarki skema klasifikasi dari masing-masing level selengkapnya disajikan pada Figure 2.

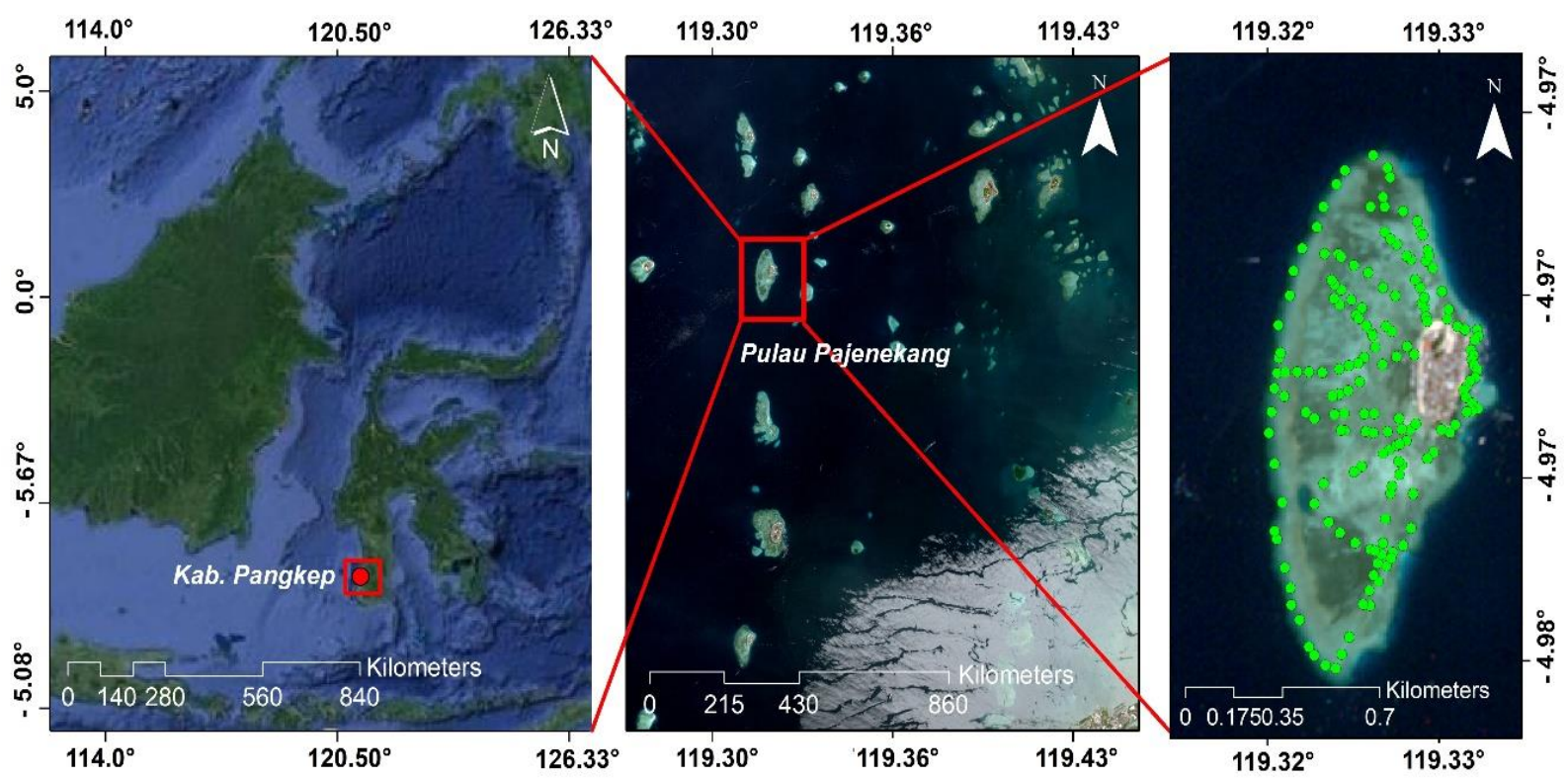

Figure 1. The coastal waters of Pajenekang Island in Pangkep Regency, South Sulawesi Province. The sampling point area is marked by a green dot around the island from north to south. 


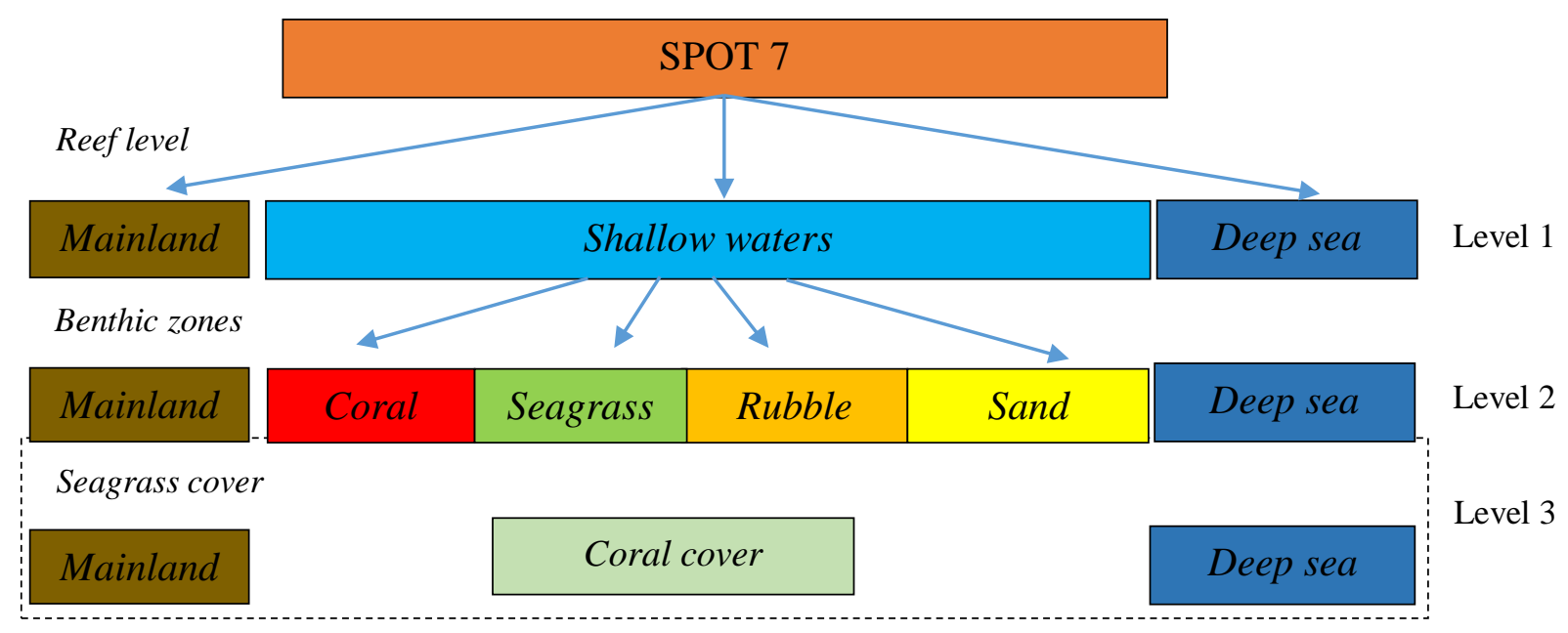

Figure 2. The image classification hierarchy structure consists of 3 levels.

Perbedaan skala pada proses segmentasi ini nantinya akan menghasilkan kumpulan layer objek citra dalam suatu jaringan hierarki. Adapun parameter yang terdapat dalam algoritma MRS ini merupakan parameter pengaturan homogenitas objek yaitu scale, shape, dan compactness (Trimble, 2014).

Tahapan selanjutnya adalah perlakuan dengan koreksi kolom air (Depth Invariant Index, DII) dan tanpa koreksi kolom air. Komposit untuk perlakuan tanpa koreksi kolom air (DII) menggunakan band merah (band 3), band hijau (band 2), dan band biru (band 1) yang kemudian dianalisis secara digital menggunakan klasifikasi berbasis objek dengan menggunakan input feature mean dari band 1 , band 2 dan band 3 . Sementara untuk koreksi kolom air digunakan kombinasi antara band hijau dan band biru. Berdasarkan penelitian Hafitz \& Danoedoro (2015) variasi band yang paling banyak menyerap nilai pantulan spektral pada perairan adalah kombinasi band biru dan hijau. Teknik koreksi kolom air DII menerapkan metode Lyzenga menggunakan nilai kemiringan regresi $(\mathrm{ki} / \mathrm{kj})$ yang dihitung berdasarkan persamaan dari Green et al. (2000). Hasil dari DII tersebut dimasukkan sebagai variabel input feature ke dalam analisis klasifikasi OBIA.
Pada proses klasifikasi level 2 dan level 3 dilakukan pendekatan algoritma klasifikasi menggunakan algoritma machine learning yaitu SVM, Bayes, DT, dan KNN. SVM memiliki vector yang berfungsi sebagai pemisah atau pembatas diantara dua kelas dengan memaksimalkan margin dari masingmasing kelas (Wahidin et al., 2015).

Bayesian adalah algoritma yang mengasumsikan bahwa vektor fitur dari masing-masing kelas terdistribusi normal (meskipun tidak harus didistribusikan secara independen) dan juga termasuk dalam klasifikasi sederhana (Fukunaga, 1990; Bradski \& Kaehler, 2008). KNN memiliki teori dasar bahwa dalam dataset kalibrasi terdapat sekelompok sampel $\mathrm{k}$ yang terdekat dengan sampel yang tidak diketahui, misalnya berdasarkan fungsi dari jarak dan pada prinsipnya setiap sampel yang dipilih untuk setiap kelas akan mencari objek sampel terdekat dalam ruang fitur untuk setiap objek gambar. Jika objek gambar adalah objek sampel terdekat milik kelas A, maka objek akan didefinisikan ke dalam kelas A (Wei et al., 2005). DT diasumsikan sebagai dasar dalam klasifikasi pada pengamatan label objek yang hampir sama dalam variabel yang berbeda. Konsep utama dalam algoritma DT ini adalah tabel yang dinyatakan dalam bentuk atribut dan data 
record (Sartika \& Sensuse, 2017). Penggunaan semua algoritma machine learning tersebut dimaksudkan untuk mencari hasil yang optimum dalam memetakan ekosistem lamun dalam hal ini untuk melihat hasil klasifikasi, kondisi, dan sebaran jenis lamun. Adapun input feature yang digunakan pada klasifikasi OBIA ini adalah Mean dari band 1, band 2, band 3 dan DII atau tanpa DII.

\subsection{Uji Akurasi}

Tahap terakhir yang dilakukan selanjutnya adalah uji akurasi dengan menggunakan confusion matrix dan nilai koefisien Kappa. Uji akurasi ini dilakukan pada level 2 dan level 3 untuk melihat hasil yang optimum dari masing-masing algoritma machine learning yang digunakan dan melihat hasil pemetaan lamun dengan menggunakan DII atau tanpa DII.

Kushardono (2017) menjelaskan bahwa confusion matrix merupakan salah satu metode pengujian akurasi untuk mengetahui nilai overall accuracy dari hasil pengolahan klasifikasi dengan membandingkan kelas-kelas hasil klasifikasi dengan kelas-kelas training data. Sedangkan indikator lain yaitu nilai koefisien Kappa yang diperoleh dengan cara membandingkan nilai akurasi keseluruhan dengan nilai akurasi yang diharapkan.

Formula uji akurasi yang digunakan berdasarkan Congalton \& Green (2009) merupakan matriks kesalahan (confusion matrix) yang menghasilkan nilai Overall Accuracy (OA), User Accuracy (UA), Producer Accuracy (PA), koefisien Kappa dan nilai $\mathrm{Z}$ statistika. Uji akurasi tersebut dapat dihitung dengan persamaan berikut:

$$
\begin{aligned}
& O A=\sum_{i=1}^{k} n i i \\
& P A=\frac{n j j}{n+j} .
\end{aligned}
$$

$U A=\frac{n i i}{n i t}$

$\mathrm{k}$ adalah jumlah baris pada matriks, $\mathrm{n}$ adalah jumlah pengamatan, $n_{i i}$ adalah jumlah pengamatan pada kolom ke-i dan baris ke-i dan $n_{\mathrm{jj}}$ merupakan jumlah pengamatan pada kolom ke-j dan baris ke-j. Sedangkan perhitungan nilai koefisien Kappa berada pada rentang 0-1 dan lebih kecil dari nilai akurasi keseluruhan yang dapat dihitung dengan rumus sebagai berikut:

$$
K=\frac{N \sum_{i=1}^{r} x_{i i-} \sum_{i}^{r}\left(x_{i+} x_{+1}\right)}{N^{2}-\sum_{i=1}^{r}\left(x_{i+} x_{+1}\right)}
$$

Keterangan: menurut Whiteside et al. (2011) $\mathrm{r}$ merupakan jumlah baris pada matriks, $x_{i i}$ adalah jumlah pengamatan baris $i$ dan kolom $i, x_{i+}$ dan $x_{+i}$ merupakan total margin baris $i$ dan kolom $i$, sedangkan $\mathrm{N}$ adalah jumlah total pengamatan (keseluruhan akurasi). Nilai koefisien Kappa inilah yang digunakan dalam penilaian akurasi untuk menentukan secara statistik apakah suatu matriks kesalahan berbeda secara signifikan dari yang lain (Congalton \& Green, 2009).

Jika $\widehat{K} 1$ dan $\widehat{K} 2$ merupakan estimasi Kappa statistik dari masing-masing matriks kesalahan \#1 dan \#2, $\widehat{\operatorname{var}}(\widehat{K} 1)$ dan $\widehat{v a r}(\widehat{K} 1)$ adalah estimasi varian sebagai hasil dari perhitungan yang tepat, maka uji statistik menggunakan persamaan:

$$
Z=\frac{\widehat{K}_{1}}{\sqrt{\operatorname{var}\left(\bar{K}_{1}\right)}}
$$

Keterangan: $\mathrm{Z}$ adalah standarisasi dan distribusi normal (standar deviasi) dengan hipotesis $H 0: K 1=0$ dan $H 1: K 1 \neq 0, H 0$ ditolak jika $Z \geq Z \alpha / 2$, dimana $\alpha / 2$ adalah tingkat kepercayaan uji $\mathrm{Z}$ dan derajat bebas diasumsikan tidak terhingga $(\infty)$. Uji statistik untuk menguji jika dua eror matriks independen berbeda secara signifikan menggunakan persamaan: 
$Z=\frac{\left|\widehat{R}_{1} \widehat{K}_{2}\right|}{\sqrt{\operatorname{var}\left(\widehat{K}_{1}\right)+\operatorname{var}\left(\widehat{R}_{2}\right)}}$

Keterangan: $\mathrm{Z}$ adalah standarisasi distribusi normal nilai Kappa dengan hipotesis $H 0$ : $(K 1-K 2)=0$, alternatif $H 1:(K 1-K 2) \neq 0, H 0$ ditolak jika $Z \geq Z \alpha / 2$.

\section{HASIL DAN PEMBAHASAN}

\subsection{Skema Klasifikasi}

Hasil analisis dari data lapangan menunjukkan bahwa habitat bentik perairan laut dangkal di lokasi penelitian terdiri dari empat kelas yaitu lamun, pasir, karang, dan rubble. Penentuan kelas habitat bentik didasarkan atas dominasi objek yang teramati di lapangan. Mastu et al. (2018) menjelaskan bahwa sampai saat ini belum ada dasar dalam pembuatan skema klasifikasi sehingga skema klasifikasi yang dibuat dalam menentukan kelas objek yang teramati untuk klasifikasi citra disesuaikan berdasarkan komposisi penyusun habitat bentik dominan yang ditemui di lapangan.
Data lapangan menunjukkan bahwa terdapat lima jenis lamun yang terdistribusi di perairan pesisir Pulau Pajenekang yang diidentifikasi berdasarkan status padang lamun di Indonesia sesuai dengan pengkelasan oleh Sjafrie et al. (2018). Jenis-jenis lamun tersebut antara lain adalah Enhalus acoroides, Thalassia hemprichii, Cymodocea rotundata, Halophila ovalis, dan Halodule uninervis (Figure 3).

Menurut Romimohtarto \& Juwana (2001), ada tiga marga yang banyak dijumpai di perairan pantai yaitu Halophila, Enhalus, dan Cymodocea. Sedangkan untuk dominasi kemunculan Thalassia di area penelitian dapat disebabkan karena kondisi substrat yang sesuai dengan jenis lamun tersebut yaitu bersubstrat pasir sampai dengan pecahan karang. Hasil penelitian sebelumnya menjelaskan bahwa lamun jenis Thalassia hemprichii umumnya banyak ditemukan di daerah rataan terumbu dengan substrat pasir dan pecahan-pecahan karang yang kasar baik yang tumbuh secara monospesifik maupun yang tumbuh dengan lamun atau tumbuhan jenis lain (Coremap, 2007).
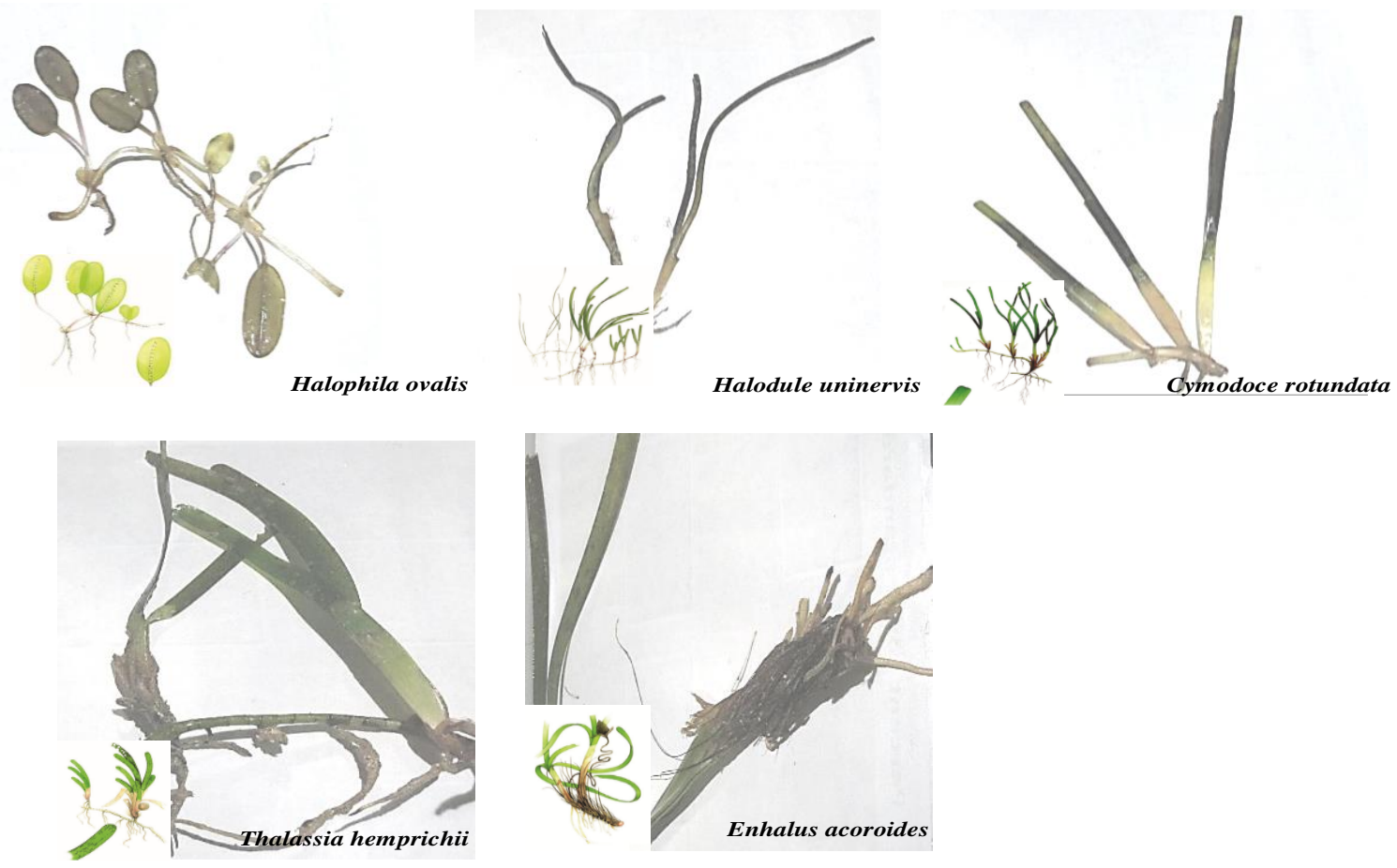

Figure 3. Types of seagrass in the waters of Pajenekang Island. 
Skema klasifikasi yang digunakan dalam penelitian ini terdiri dari 3 level. Level 1 yaitu reef level yang terdiri dari pengkelasan darat, laut dalam, dan perairan dangkal. Level 2 merupakan pengkelasan habitat bentik dasar perairan laut dangkal (lamun, pasir, karang, dan rubble). Sedangkan level 3 merupakan pengkelasan kondisi tutupan lamun (rapat, kurang rapat, dan jarang). Penentuan kondisi ini berdasarkan dari Kepmen Lingkungan Hidup No.200 Tahun 2004 tentang Kriteria Baku Kerusakan dan Pedoman Penentuan Status Padang Lamun.

\subsection{Klasifikasi Citra dengan Penerapan Koreksi Kolom Air (Depth Invariant Index) dan Tanpa Koreksi Kolom Air}

Proses utama yang dilakukan dalam penerapan metode ini adalah mencari nilai koefisien atenuasi $(\mathrm{Ki} / \mathrm{Kj})$ dari lokasi penelitian untuk perairan Pulau Pajenekang dengan mengekstrak nilai digital dari kombinasi kanal biru dan hijau, karena kanal biru dan hijau sangat baik untuk penetrasi (Suwargana, 2014). Setelah itu dicari nilai covarian dan varian dari training sampel pada masing-masing kanal, kemudian didapatkan nilai koefisien atenuasi yang diterapkan ke dalam klasifikasi digital citra satelit. Nilai koefisien atenuasi $(\mathrm{Ki} / \mathrm{Kj})$ yang diperoleh sebesar 0,53501. Training sampel yang dilakukan pada substrat dasar perairan berdasarkan metode Lyzenga (1981) berada pada kedalaman yang berbeda dan homogen agar mendapatkan nilai korelasi yang linier dengan DII.

Hasil DII yang diperoleh pada penelitian ini juga diterapkan pada beberapa algoritma machine learning (SVM, DT, KNN, dan Bayes) untuk klasifikasi kelas habitat bentik dan kondisi tutupan lamun. Selain itu, masing-masing algoritma machine learning yang ada diujikan dengan perlakuan tanpa koreksi kolom air (tanpa DII), sehingga dapat diketahui penerapan metode dan algoritma machine learning yang digunakan pada lokasi penelitian. Hasil klasifikasi level 2 dan level 3 untuk tiap algoritma yang diujikan pada masing-masing perlakuan dapat dilihat pada Figure 4 dan 5.

Secara spasial hasil klasifikasi masing-masing algoritma pada Figure 4 menunjukkan hasil yang tidak jauh berbeda untuk tiap level dan perlakuan. Pada Figure 3 dilakukan klasifikasi kelas habitat bentik yang terdiri dari kelas lamun, karang, rubble dan pasir. Masing-masing algoritma yang diujikan pada perlakuan tanpa koreksi dan dengan koreksi kolom air secara visual tidak menunjukkan perbedaan yang cukup signifikan. Selain itu, hasil klasifikasi pada level 2 juga menunjukkan bahwa untuk masing-masing objek yang dikelaskan, kelas rubble terlihat lebih dominan dibandingkan kelas lainnya pada penerapan algoritma Bayes.

Hasil perbandingan beberapa algoritma yang ditampilkan pada kedua gambar diatas (Figure 3) secara umum juga dapat menjelaskan bahwa penggunaan algoritma klasifikasi pada suatu lokasi atau kasus penelitian tidak serta merta dapat disamakan. Faktor kemiripan nilai spektral menurut Mastu (2018) tidak dapat dihindari oleh algoritma klasifikasi, terutama kelas habitat bentik yang disusun oleh beberapa kelas habitat bentik dalam lokasi pengamatan.

Figure 5 terlihat bahwa klasifikasi objek lamun berdasarkan kelas kondisi tutupan lamun terbagi menjadi tiga kelas, yaitu kaya/sehat, kurang kaya, miskin. Berdasarkan hasil perlakuan yang telah dilakukan yaitu tanpa penerapan koreksi kolom air dan dengan koreksi kolom air tidak terjadi penambahan ataupun pengurangan kelas untuk masing-masing kondisi tutupan lamun. Akan tetapi, secara visual dapat dilihat bahwa pada masing-masing kelas kondisi tutupan lamun yang telah dilakukan koreksi kolom air terdapat perbedaan dalam hal distribusi kelas kondisi tutupan lamun pada beberapa area tertentu. Distribusi kelas kaya/sehat dan kurang kaya terlihat lebih 

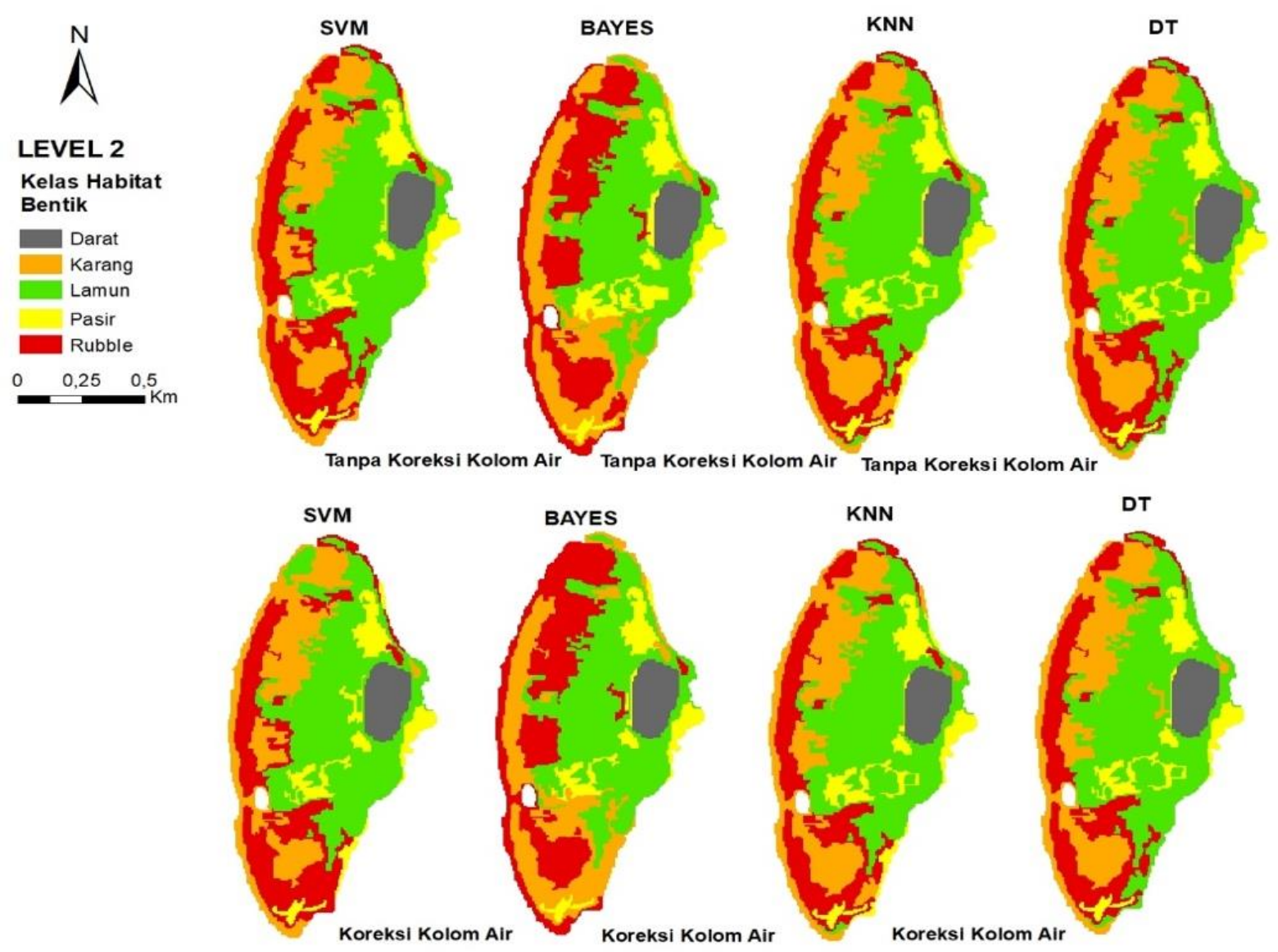

Figure 4. The results of image classification level 2 (benthic habitat class) with the application of water column correction and without water column correction on SVM, Bayes, KNN and DT classification algorithms.

mendominasi setelah dilakukan koreksi kolom air dibandingkan dengan kelas miskin (rusak). Perbedaan perlakuan pada kondisi tutupan lamun terlihat jelas pada pengujian menggunakan algoritma SVM, dimana sebelum dilakukan koreksi kolom air kelas dominan adalah kelas dengan kondisi tutupan kurang kaya. Setelah dilakukan koreksi kolom air terlihat terjadi perubahan dan kelas yang dominan adalah kelas dengan kondisi tutupan kaya/sehat.

Perubahan tersebut dapat diakibatkan karena tidak adanya pengaruh koreksi kolom air pada refleksi spectral, pada kelas tutupan kurang kaya dan setelah dilakukan koreksi kolom air kejelasan objek pada kelas kaya/sehat lebih jelas, serta adanya pengaruh dari variasi kekeruhan dan kedalaman terhadap koreksi kolom air. Thalib et al.
(2018) menjelaskan bahwa variasi kedalaman dan kekeruhan dapat mempengaruhi kolom air sehingga di-perlukan koreksi kolom air untuk mengurangi pengaruh kolom air dengan algoritma Lyzenga yang diasumsikan dapat memberikan informasi karakteristik dasar perairan dangkal dengan lebih jelas.

\subsection{Uji Akurasi}

Berdasarkan hasil perhitungan confusion matrix nilai akurasi yang diperoleh dari penerapan koreksi kolom air dan tanpa koreksi kolom air untuk masing-masing algoritma klasifikasi menunjukkan nilai akurasi yang secara signifikan tidak berbeda jauh (Table 1). Umumnya nilai akurasi masing-masing algoritma klasifikasi yang diterapkan menunjukkan nilai yang baik, sesuai perlakuan atau inputan yang diberikan. 

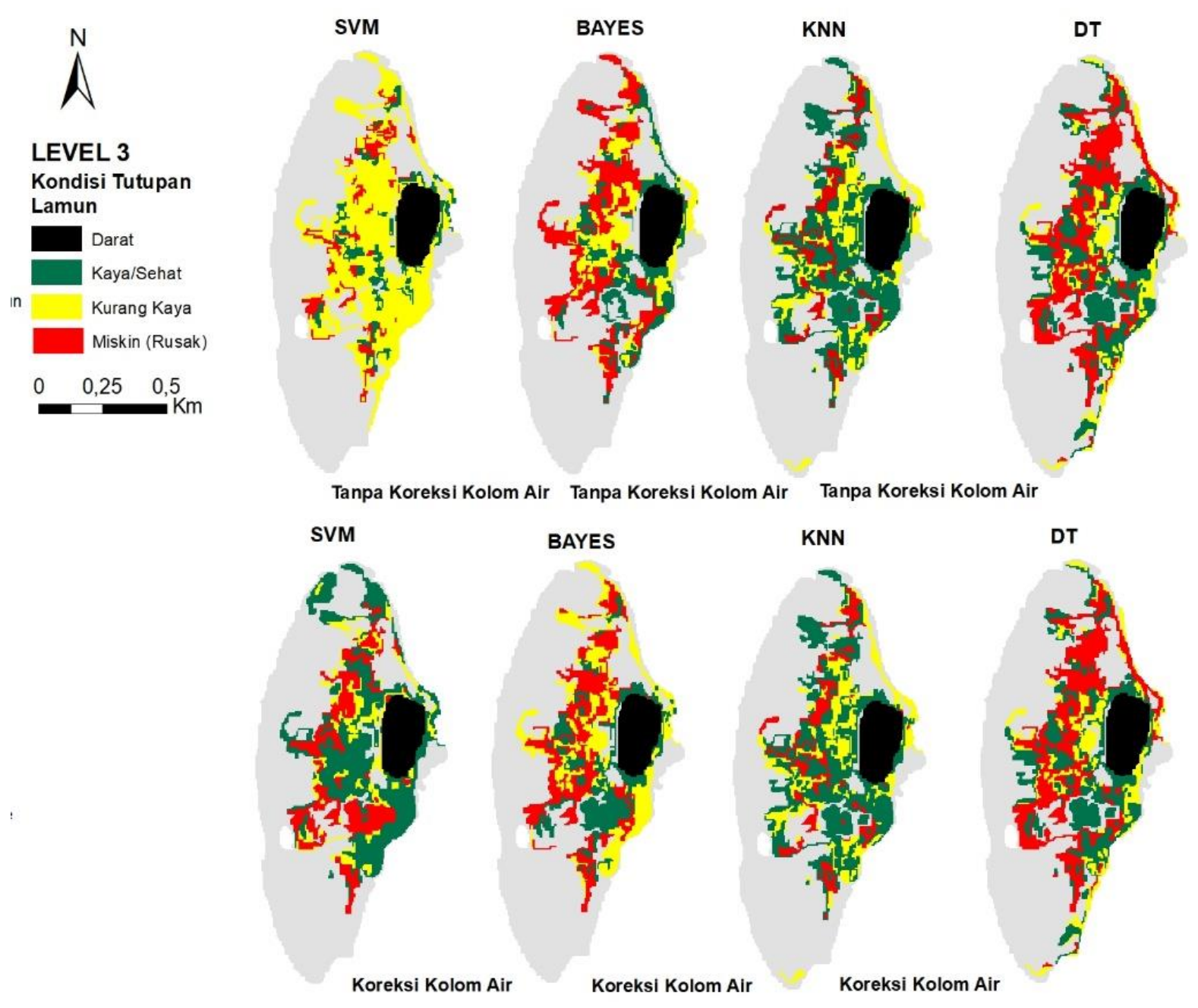

Figure 5. Level 3 image classification results (seagrass cover conditions) by applying water column correction and without water column correction on SVM, Bayes, KNN and DT classification algorithms.

Table 1. The total accuracy value of benthic habitat class classification (level 2) and seagrass cover conditions (level 3) SPOT 72017 images with and without DII correction on several classification algorithms.

\begin{tabular}{cccccc}
\hline \multirow{2}{*}{ No. } & \multirow{2}{*}{$\begin{array}{c}\text { Classification } \\
\text { Algorithm }\end{array}$} & $\begin{array}{c}\text { Without DII } \\
(\%)\end{array}$ & $\begin{array}{c}\text { With } \\
\text { DII (\%) }\end{array}$ & $\begin{array}{c}\text { Without } \\
\text { DII (\%) }\end{array}$ & Dith \\
& & 66.8 & 66.8 & 60.69 & 56.07 \\
\hline 1. & SVM & 70.36 & 69.17 & 66.47 & 65.89 \\
2. & Bayes & 66.8 & 66.8 & 63.01 & 63.01 \\
3. & KNN & 67.19 & 67.19 & 55.49 & 55.49 \\
4. & DT & & & & \\
\hline
\end{tabular}

Pada umumnya hasil akurasi dari beberapa algortima klasifikasi yang diujikan dengan penerapan koreksi kolom air dan tanpa koreksi kolom air masing-masing menunjukkan bahwa nilai akurasi pada klasifikasi habitat bentik (level 2) cukup baik 
(>65\%) dan nilai terbaik diperoleh pada algoritma Bayes dengan nilai akurasi 70,36\% pada perlakuan tanpa koreksi kolom air dan 69,17\% dengan perlakuan koreksi kolom air. Pada level 3 untuk klasifikasi kondisi lamun juga menunjukkan hasil yang optimal dan terbaik dihasilkan oleh algoritma klasifikasi Bayes tanpa perlakuan koreksi kolom air sebesar $66,47 \%$ dan dengan koreksi kolom air sebesar 65,89\%. Menurut Putri et al. (2004) algoritma Bayes merupakan algoritma pengkelasan yang berdasarkan probabilitas sederhana dan dirancang untuk dipergunakan dengan alasan bahwa antar satu kelas dengan kelas yang lain tidak saling tergantung (independen). Selain itu Han \& Kamber (2006) juga menjelaskan bahwa keuntungan pengklasifikasian dengan menggunakan pendekatan ini dapat memperkecil nilai eror atau kesalahan klasifikasi. Kayabol \& Kutluk (2016) dalam penelitiannya memberikan kesimpulan bahwa Bayes dapat digunakan dalam jumlah sampel data yang kecil dan memberikan hasil yang baik dalam melakukan klasifikasi. Sementara itu rendahnya nilai akurasi dari algoritma lainnya menurut Mastu (2018) dapat dipengaruhi oleh kompleksitas habitat bentik dalam hal ini lamun yang terdapat di lokasi penelitian dan jumlah titik pengamatan.

Beberapa kasus algoritma klasifikasi tertentu dapat menghasilkan nilai akurasi yang tinggi apabila input data dan pemrosesan citra yang dilakukan sesuai. Selain itu tingginya kompleksitas habitat dan ketidaksesuaian antara akurasi GPS dan resolusi spasial citra juga dapat menyebabkan rendahnya akurasi (Anggoro et al., 2017). Selain hasil dari nilai overall accuracy, Congalton \& Green (2009) menjelaskan bahwa untuk mengetahui perbedaan signifikan dari nilai akurasi hasil klasifikasi dapat dilakukan dengan analisis melalui nilai Kappa dan Z statistika. Nilai Z statistika yang diperoleh menggambarkan seberapa signifikan perbedaan yang diperoleh dari masing-masing perlakuan (Table 2 dan 3).
Table 2. Test values are significant comparisons of several classification algorithms at level 2 with and without water column correction (DII).

\begin{tabular}{lcc}
\hline Algorithm & $\begin{array}{c}\text { Z Level 2 } \\
\text { statistics } \\
\text { without DII } \\
\text { and with DII }\end{array}$ & $\begin{array}{c}\text { Z Table } \\
(\alpha=0.05)\end{array}$ \\
\hline SVM & 0.01 & 1.96 \\
Bayes & 0.46 & 1.96 \\
KNN & 0.00 & 1.96 \\
DT & 0.00 & 1.96 \\
\hline
\end{tabular}

Table 3. Test values are significant comparisons of several classification algorithms at level 3 with and without water column correction (DII).

\begin{tabular}{lcc}
\hline Algorithm & $\begin{array}{c}\text { Z Level 3 } \\
\text { statistics } \\
\text { without DII } \\
\text { and with DII }\end{array}$ & $\begin{array}{c}\text { Z Table } \\
(\alpha=0.05)\end{array}$ \\
\hline SVM & 0.31 & 1.96 \\
Bayes & 0.12 & 1.96 \\
KNN & 0.00 & 1.96 \\
DT & 0.00 & 1.96 \\
\hline
\end{tabular}

Table 2 dan 3 memperlihatkan nilai hasil $\mathrm{Z}$ statistik yang telah diuji pada level 2 dan level 3. Pada Table 3 dihasilkan nilai $\mathrm{Z}$ statistik lebih kecil dari nilai $\mathrm{Z}$ tabel dengan nilai alpha yang ditentukan adalah $\alpha / 2$ $(0.05 / 2=0.025)$. Nilai alpha $(\alpha)$ merupakan taraf signifkan yang nilainya tetap dan tidak berubah-ubah berapapun jumlah sampel yang dilihat dari nilai $\mathrm{Z}$ dari luas di bawah nilai kurva normal baku. Hal yang sama juga terlihat pada Table 4, dimana nilai $\mathrm{Z}$ statistik yang dihasilkan pada level 3 nilainya lebih kecil dari nilai $\mathrm{Z}$ tabel. Nilai $\mathrm{Z}$ statistik yang diperoleh dari kedua tabel diatas (Table 2 dan 3) adalah hasil yang dihitung berdasarkan nilai akurasi dari masing-masing algoritma yang diuji dengan perlakuan tanpa koreksi kolom air dan dengan koreksi kolom 
air untuk mengetahui jika dua matriks kesalahan independen berbeda secara signifikan.

Hasil dari nilai $\mathrm{Z}$ statistika dari masing-masing perlakuan menjelaskan bahwa hasil akurasi masing-masing algoritma dengan kedua perlakuan tersebut dikategorikan terdistribusi normal tetapi tidak menunjukkan perbedaan yang signifikan. Perbandingan nilai $\mathrm{Z}$ tabel dengan nilai $\mathrm{Z}$ hitung yang didapat dari masingmasing algoritma menunjukkan bahwa nilai $\mathrm{Z}$ hitung atau $\mathrm{Z}$ statistik lebih kecil dari nilai $\mathrm{Z}$ tabel, yang artinya hipotesis awal diterima dan tidak ada perbedaan yang nyata (sama) antara masing-masing algoritma yang diujikan dengan perlakuan tanpa koreksi kolom air dan dengan koreksi kolom air pada tiap level. Hal ini sesuai hipotesis awal yang telah ditentukan dan berlaku pada rumus uji statistik (uji Z) yang menentukan kriteria bahwa $\mathrm{Z}$ adalah standarisasi distribusi normal nilai Kappa dengan hipotesis $H 0$ : $(K 1$ $-K 2)=0$, alternatif $H 1:(K 1-K 2) \neq 0, H 0$ ditolak jika $Z \geq Z \alpha / 2$ (Congalton \& Green, 2009).

\section{KESIMPULAN}

Penerapan perlakuan dengan koreksi kolom air dan tanpa koreksi kolom air pada pemetaan ekosistem habitat bentik dan lamun dengan menggunakan beberapa algoritma klasfikasi (SVM, Bayes, KNN, dan DT) menunjukkan hasil akurasi yang tidak berbeda nyata. Namun demikian, dari empat algoritma yang digunakan, algoritma Bayes tanpa koreksi kolom air memberikan nilai akurasi tertinggi untuk pemetaan habitat bentik dengan nilai $70,36 \%$ dan habitat lamun sebesar $66,47 \%$.

\section{UCAPAN TERIMA KASIH}

Penelitian ini dibiayai oleh Kementrerian Riset, Teknologi, dan Pendidikan Tinggi, Republik Indonesia sesuai dengan Perjanjian Penugasan
Pelaksanaan Penelitian dan Pengabdian kepada Masyarakat di Perguruan Tinggi Negeri Badan Hukum Tahun Anggaran 2019 antara Direktorat Jenderal Penguatan Riset dan Pengembangan, Kemenristekdikti dengan Insitut Pertanian Bogor Nomor:3/E1/KP. PTNBH/2019 tanggal 29 Maret 2019 dan Surat Perjanjian Penugasan Penelitian bagi Dosen IPB PMDSU No. 4253/IT3.L1/ PN/2019 tanggal 4 April 2019, dalam rangka pelaksanaan kegiatan Penelitian Pendidikan Magister Menuju Doktor untuk Sarjana Unggul (PMDSU) tahun ajaran 2019/2020. Penulis juga mengucapkan terima kasih kepada Lembaga Penerbangan dan Antariksa Nasional (LAPAN) dalam menyediakan data citra satelit SPOT-7.

\section{DAFTAR PUSTAKA}

Anggoro, A., V.P. Siregar, \& S.B. Agus. 2017. Klasifikasi multiskala untuk pemetaan zona geomorfologi dan habitat bentik menggunakan metode OBIA di Pulau Pari. J. Penginderaan Jauh, 14(2): 89-93. http://doi.org/10.30536/j.pjpdcd.1017. v14.a2622

Aziizah, N.N., V.P. Siregar, \& S.B. Agus. 2016. Penerapan algoritma spectral angle mapper (SAM) untuk klasifikasi lamun menggunakan citra satelit Worldview-2. J. Penginderaan Jauh, 13(2): 61-72.

http://doi.org/10.30536/j.pjpdcd.2016. v13.a2205

Bradski, G. \& A. Kaehler. 2008. Learning opencv: Computer vision with the opencv library. O'Reilly Media, Inc. Sebastopol, CA, USA. 555 p.

Budhiman, S., G. Winarso, \& W. Asriningrum. 2013. Pengaruh pengambilan training sample substrat dasar berbeda pada koreksi kolom air menggunakan data penginderaan jauh. J. Penginderaan Jauh, 10(2): 83-92. 
Bukata, R.P., J.H. Jerome, A.S. Kondratyev, \& D.V. Pozdnyakov. 2018. Optical properties and remote sensing of inland and coastal waters. CRC Press. Boca Raton. 384 p.

Congalton, R.G. \& K. Green 2009. Assessing the accuracy of remotely sensed data principles and practices (Second Edition). CRC Taylor \& Francis Group. France. 183 p.

COREMAP CTI. 2007. Lamun. http://www.coremap.or.id/datin/seagr ass. [diunduh 23 Februari 2019].

Dekker, A.G., V.E. Brando, \& J.M. Anstee. 2005. Retrospective seagrass change detection in a shallow coastal tidal Australian lake. Remote Sensing of Environment, 97: 415-433. https://doi.org/10.1016/j.rse.2005.02.0 17

Fukunaga, K. 1990. Introduction to statistical pattern recognition (2nd ed.). Academic Press. New York. 591 p.

Green, E., A.J. Edwards, \& C. Clark. 2000. Remote sensing handbook for tropical coastal management. Unesco Pub. Paris (FR). 316 p.

Hafitz, M. \& P. Danoedoro. 2015. Kajian pengaruh koreksi kolom air pada citra multispektral Worldview-2 untuk pemetaan habitat bentik di Pulau Kemujan Kepulauan Karimunjawa Kabupaten Jepara. Jogjakarta. Prosiding Pertemuan Ilmiah Tahunan XX 2015, Jogjakarta, Februari 2015. 566-575 pp.

Han, J. \& M. Kamber. 2006. Data Mining Concepts and Techniques, second edition. Morgan Kaufman. California. $135 \mathrm{p}$.

Hedley, J., C. Roelfsema, \& S.R. Phinn, 2009. Efficient radiative transfer model in- version for remote sensing applications. Remote Sensing of Environment, 113: 2527-2532. https://doi.org/10.1016/j.rse.2009.07.0 08

Hossain, M.S., J.S. Bujang, M.H. Zakaria, \& M. Hashim. 2015. Application of Landsat images to seagrass areal cover change analysis for Lawas, Terengganu and Kelantan of Malaysia. Continental Shel Research, 110: 124-148. https://doi.org/10.1016/j.csr.2015.10. 009

Kayabol, K. \& S. Kutluk. 2016. Bayesian classification of hyperspectral image using spatially-varying Gaussian mixture model. Digital Signal Processing, 59: 106-114. https://doi.org/10.1016/j.dsp.2016.08. 010

Kushardono, D. 2017. Klasifikasi digital pada penginderaan jauh. IPB Press. Bogor. 76 p.

Lyzenga, D.R. 1981. Remote sensing of bottom reflectance and water attenuation parameters in shallow water using aircraft and landsat data. International J. Remote Sensing, 2: 171-172. https://doi.org/10.1080/01431168108 948342

Macreadie, P.I., M.E. Baird, S.M. Trevathan, A.W.D. Larkum, \& P.J. Ralph, 2014. Quantifying and modelling the carbon sequestration capacity of seagrass meadows - a critical assessment. Mar. Pollut. Bull., 83: 430-439. https://doi.org/10.1016/j.marpolbul. 2013.07.038

Mastu, L.K., B. Nababan, \& J.P. Panjaitan. 2018. Pemetaan habitat bentik berbasis objek menggunakan citra Sentinel-2 di perairan Pulau WangiWangi, Kabupaten Wakatobi. J. Ilmu dan Teknologi Kelautan Tropis, 10(2): 381-396.

http://doi.org/10.29244/jitkt.v10i2.21 039 
McKenzie, L.J., S.J. Campbell, \& C.A. Roder. 2003. Seagrass-watch: manual for mapping \& monitoring seagrass resources by community (citizen) volunteers. 2nd Edition. (QFS, NFC, Cairns). $100 \mathrm{p}$.

Phinn, S.R., C.M. Roelfsema, \& P.J. Mumby. 2011. Multi scale object based image analysis for mapping geomorphic and ecological zones on coral reefs. International J. Remote Sensing, 33: 3768-3797.

https://doi.org/10.1080/01431161.201 1.633122

Putri, R.E., Suparti, \& R. Rahmawati. 2014. Perbandingan metode klasifikasi Naibe Bayes dan K-Nearest Neighbour pada analisis data status kerja di Kabupaten Demak Tahun 2012. J. Gaussian, 3(4): 831-838.

Prabowo, N.W., V.P. Siregar, \& S.B. Agus. 2018. Klasifikasi habitat bentik berbasis objek dengan algoritma support vector machines dan decision tree menggunakan citra multispectral SPOT-7 di Pulau Harapan dan Pulau Kelapa. J. Ilmu dan Teknologi Kelautan Tropis, 10(1): 123-134. http://doi.org/10.29244/jitkt.v10i1.21 670

Roelfsema, C., S. Phinn, S. Jupiter, J. Comley, \& S. Albert. 2013. Mapping coral reefs at reef to reef-system scales, 10s-1000s $\mathrm{km}^{2}$, using objectbased image analysis. International $J$. Remote Sensing, 34(18): 6367-6388. https://doi.org/10.1080/01431161.201 3.800660

Romimohtarto, K. \& S. Juwana. 2001. Biologi Laut: Ilmu Pengetahuan Tentang Biota Laut. Djambatan. Jakarta. 540 p.

Sartika, D. \& D.I. Sensuse. 2017. Perbandingan algoritma klasifikasi naive bayes, nearest neighbour, dan decision tree pada studi kasus pengambilan keputusan pemilihan. Jatisi, 1(2): 151-161. https://doi.org/10.35957/jatisi.v3i2.78

Setiawan, K.T., M.D.M. Manessa, G. Winarso, N. Anggraini, G. Giarrastowo, W. Asriningrum, Herianto, S. Rosid, \& A.H. Supardjo. 2019. Estimasi batimetri dari data spot 7 studi kasus perairan Gili Matra Nusa Tenggara Barat. $J$. Penginderaan Jauh, 15(2): 69-82. http://doi.org/10.30536/j.pjpdcd.2018. v15.a3008

Sjafrie, N.D.M., U.E. Hernawan, B. Prayudha, I.H. Supriyadi, M.Y. Iswari, Rahmat, K. Anggraini, S. Rahmawati, \& Suyarso. 2018. Status padang lamun indonesia Ver. 02. LIPI. Jakarta. 40 p.

Suwargana, N. 2014. Analisis citra ALOS AVNIR-2 untuk pemetaan terumbu karang (studi kasus: Banyuputih, Kab. Situbondo). Prosiding Deteksi Parameter Geobiofisik Dan Diseminasi Penginderaan Jauh Seminar Nasional Penginderaan Jauh 2014. 588-596 pp.

Thalib, M.S., N. Nurdin, \& A. Aris. 2018. The ability of lyzenga's algorithm for seagrass mapping using sentinel-2a imagery on Small Island, Spermonde Archipelago, Indonesia. Proceeding of IOP Conference Series: Earth and Environmental Science, 165(1): 012028.

https://doi.org/10.1088/17551315/165/1/012028

Traganos, D., B. Anggarwal, D. Poursanidis, K. Topouzelis, N. Chrysoulakis, \& P. Reinartz. 2018. Towards global-scale seagrass mapping and monitoring using sentinel-2 on google earth engine: the case of the Aegean and Ionian Seas. MDPI J., 10(8): 1227. https://doi.org/10.3390/rs10081227

Trimble. 2014. Ecognition developer: user guide. Trimble Germany $\mathrm{GmbH}$. Munchen, Germany. 262 p.

Wahidin, N., V.P. Siregar, B. Nababan, I. Jaya, \& S. Wouthuyzend. 2015. 
Object based image analysis for coral reef benthic habitat mapping with several classification alghorithms. Procedia Environmental Sciences, 24: 222-227.

https://doi.org/10.1016/j.proenv.2015. 03.029

Waycott, M., K. Mcmahon, J. Mellors, A. Calladine, \& A.D. Kleine. 2004. A guide to tropical seagrasses of the Indo-West Pacific. James Cook University. Townsville. 72 p.

Wei, W., X. Chen, \& A. Ma. 2005. Objectoriented information extraction and application in high-resolution remote sensing image. IEEE International Geoscience and Remote Sensing Symposium, 8: 3803-3807. https://doi.org/10.1109/IGARSS.2005 .1525737

Whiteside, T.G., G.S. Boggs, \& S.W. Maier. 2011. Comparing object-based and pixelbased classifications for mapping savannas. International J. of Applied Earth Observation and Geoinformation, 13(6): 884-893. https://doi.org/10.1016/j.jag.2011.06.

008

Yang, D. \& C. Yang. 2009. Detection of seagrass distribution changes from 1991 to 2006 in Xincun Bay, Hainan, with satellite remote sensing. Sensors, 9:830-844. https://doi.org/10.3390/s90200830

Zhang, C. 2015. Applying data fusion techniques for benthic habitat mapping. ISPRS J. of Photogrammetry and Remote Sensing, 104: 213-223. https://doi.org/10.1016/j.isprs jprs.2014.06.005

Zoffoli, M.L., R. Frouin, \& M. Kampel. 2014. Water Column for Coral Reef Studies by Remote Sensing. Sensors J., 14(9): 16881-16931. https://doi.org/10.3390/s140916881

Received : 10 July 2019

Reviewed :02 September 2019

Accepted : 25 January 2020 
